\title{
トンボ型羽ばたき飛行における羽ばたき位相差と飛行速度*
}

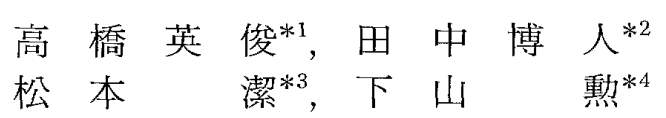

\section{Flight Mode Change with Wing Phase Relationship of Dragonfly-Type Flight}

\author{
Hidetoshi TAKAHASHI ${ }^{* 5}$, Hiroto TANAKA, \\ Kiyoshi MATSUMOTO and Isao SHIMOYAMA \\ ${ }^{* 5}$ Graduate School of Information Science and Technology, The University of Tokyo, \\ 7-3-1 Hongo, Bunkyo-ku, Tokyo, 113-8656 Japan
}

\begin{abstract}
In this research, Dragonfly-type Ornithopers (DTOs) were developed to reveal the effect of the phase relationship between forewings and hindwings on flight performance. The DTO has high aspect four wings. The Reynolds number of the ornithopter is the same order as that of real dragonflies $\left(10^{3}-10^{4}\right)$. The DTO's phase relationship ranges from $0^{\circ}$ to $315^{\circ}$ with $45^{\circ}$ intervals. Flights of DTOs with various phase relationships were recorded with a high speed video camera, and their motions were analyzed. In the stable flight, the flight speed varied depending on the phase relationship. We also visualized the airflow around the wings in a wind tunnel. It was revealed that there were suitable phase relationships for accelerating flight $\left(45^{\circ}\right)$, low speed flight $\left(180^{\circ}\right)$ and high speed flight $\left(270^{\circ}, 315^{\circ}\right)$. This relationship between the flight mode and the phase relationship was in good agreement with that of dragonflies.
\end{abstract}

Key Words: Dragonfly, Phase Relationship, Ornithopter, Flapping Flight, Bio-Fluid Mechanics, Unsteady Flow, Biomechanics

\section{1. 緒言}

昆虫は羽ばたき運動によって飛行し，ホバリング, 急旋回などを行うことができる. 長年, これら昆虫の 羽ばたき飛行のメカニズムを解明しようと多くの研究 がなされている(1) (7). しかし羽ばたき飛行において は，非定常な空気力(4) (7) が発生するため, 飛行メ力二 ズムは末だに解明されていない部分が多い.

昆虫の中でも，トンボはホバリング，急加速，急旋 回など非常に優れた機動力を実現している(8). トンボ の特徵は，翅の運動自由度が大きく，4枚の翅がそれ ぞれ独立にフラッピング，リードラグ，フェザリング 運動できることである。この中で前翅の後翅の羽价た き運動に位相差をつけることが, 前翅が発生する流れ と後翅の流れが干渉し, 優れた機動力を実現する重要 な要因の 1 つになっていると考えられている，実際， トンボの前翅と後翅の羽ばたき運動の位相差(以後,

* 原稿受付 2010 年 2 月 12 日.

*1 正員, 東京大学大学院情報理工学系研究科 (是 113-8656 東 京都文京区本郷 7-3-1).

*2 正員, ハーバード大学工学応用科学大学院(60 Oxford Street 407, Cambridge MA 02138, USA).

*3 正員, 東京大学 IRT 研究機構

*4 正員, フェロ一, 東京大学大学院情報理工学系研究科.

E-mail : takahashi@leopard.t.u-tokyo.ac.jp
位相差と略す)は飛び方に応じて異なることが知られ ている(8) (10).エリントンら(9)によるとトンボは高速 で前進飛行する場合, 羽ばたき位相差 $260^{\circ}$ から $306^{\circ}$ の間で飛行する。ホバリングや旋回運動といつた飛行 の場合，位相差 $180^{\circ}$ で飛行する。また離陸や急加速 といった飛行の場合，前翅と後翅は同期し，位相差 $0^{\circ}$ で飛行する。しかしトンボは位相差だけでなく、フラ ッピング角やフェザリング角, 羽ばたき周波数などを 同時飞変えているため，トンボの観察による研究では 羽ばたき位相差のみの影響を抽出することは難し い(11) (13)

羽ばたき位相差が飛行にとって，どのような役割を 持つかを調べるために数值計算による解析 ${ }^{(14)(15)}$ も行 われているが, 前翅が発生する流れと後翅の流れが干 渉し合うため複雑で, 計算手法は完全には確立してい ない。また羽ばたき運動時のレイノルズ数を合わせた 油中での人工の翅を用いた羽ばたき運動の解析(16)も 行われているが，羽ばたき位相差の違いによる力の発 生の計測にとどまっている。

そこで本研究では，羽ばたき位相差の違いによる飛 行の変化を調べるために，羽洁たき位相差のみが異な るトンボ型羽ばたき機を試作し，その飛行を高速度力 メラで撮影し計測する。人工の羽ばたき機を用いるこ 
とによって，飛行と羽ばたき位相差の関係を明確に捕 らえることが可能となり，再現性のある笑験を行え る。また羽ばたき位相差が流れに与える影響を調べる ために，風洞内で羽ばたき機まわりの流れの可視化実 験を行う。これらの実験からトンボ型羽ばたき飛行に おける羽ばたき位相差の役割を明らかにする。

\section{2. トンボ型羽ばたき機}

$2 \cdot 1$ パラメータの定義 本研究では絶対座標系 における $x$ 方向の速度を $V_{x}$ とする [図 1(a)]。体 軸角 $\alpha$ は体軸と水平面がな寸角度である。また羽ば たき位相差を以下のように定義する。本研究では前翅 と後翅の羽ばたき周波数 $\omega$ と羽ばたさ振幅 $A$ を一定 とし，前翅抢よび後翅の体軸に対する角度 $\theta_{f}, \theta_{h}$ が

$$
\begin{aligned}
& \theta_{f}=A \sin (\omega t) \cdots \\
& \theta_{h}=A \sin (\omega t-\varphi)
\end{aligned}
$$

であると仮定する[図1(b)]。このときの たき位相差と定義する。すなわち前翅に対する, 後翅 の位相遅れ分を羽ばたき位相差 $\varphi$ として定義してい る.

$2 \cdot 2$ トンボのモデル化＼cjkstart本節ではトンボの特徴 を抽出し，トンボ型羽ばたき機の設計指針とする。本 研究で刘象とするのは，才ニヤンマのような大型のト ンボである。

飛行する生物の翼は，翼の形状，飛行時に扔けるレ イノルズ数, 翼面荷重 (重量/翼面積)によって分類で きる。

トンボの翅はチョウやセミなどに比べ翼長方向と翼 弦方向のアスペクト比が大きく, 3.0 から 5.0 程度で ある。また飛行中のレイノルズ数は翼幅方向半分の位 置では $10^{3}$ から $10^{4}$ のオーダである。構造は, 網状の 細い梁と薄い膜で形成されている.

東らはトンボ, チョウ, セミの羽ばたき周波数と翼 面荷重の関係を調べている(17)。これによると翼面荷 重は,トンボやチョウは小さく, $0.5 \mathrm{~N} / \mathrm{m}^{2}$ から $4 \mathrm{~N} /$ $\mathrm{m}^{2}$ である。セミは $5 \mathrm{~N} / \mathrm{m}^{2}$ から $20 \mathrm{~N} / \mathrm{m}^{2}$ と大きい.

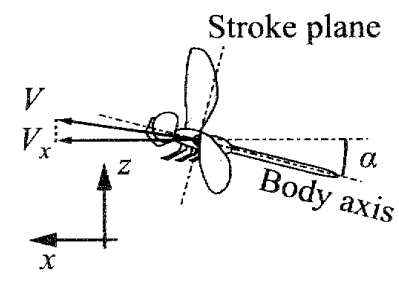

(a)

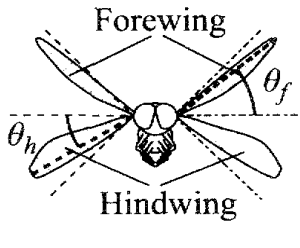

(b)
Fig. 1 Definition of parameters. (a) Side view, (b) Front view along stroke plane
したがって，トンボの特徴を以下のようにモデル化し， トンボ型羽ばたき機の設計指針とした。

(1) レイノルズ数: $10^{3} \sim 10^{4}$

(2) 翅の形状:アスペクト比が 3 から 5

（3）翼面荷重: $0.5 \sim 4.0 \mathrm{~N} / \mathrm{m}^{2}$

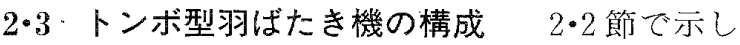
た設計指針を満たすトンボ型羽ばたき機を試作した。 その外観を図 2 に示す。また表 1 に羽ばたき機の各パ ラメータを示す。翅はゴムの回軽星スライダクランク

Table 1 Characteristics of the DTO

\begin{tabular}{|l|c|}
\hline Wing span $(\mathrm{mm})$ & 100 \\
\hline Wing loading $\left(\mathrm{N} / \mathrm{m}^{2}\right)$ & 1.3 \\
\hline Aspect ratio of wing & 3.3 \\
\hline Reynolds number & $10^{3}$ \\
\hline Flapping frequency $(\mathrm{Hz})$ & 10 \\
\hline Weight $(\mathrm{g})$ & 0.8 \\
\hline
\end{tabular}

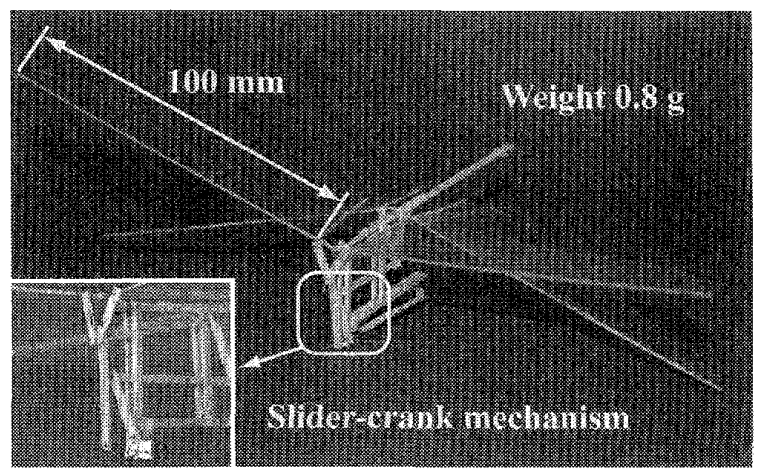

Fig. 2 Photograph of a Dragonfly-type Ornithopter (DTO)

(a)

(b) Forewing Hindwing

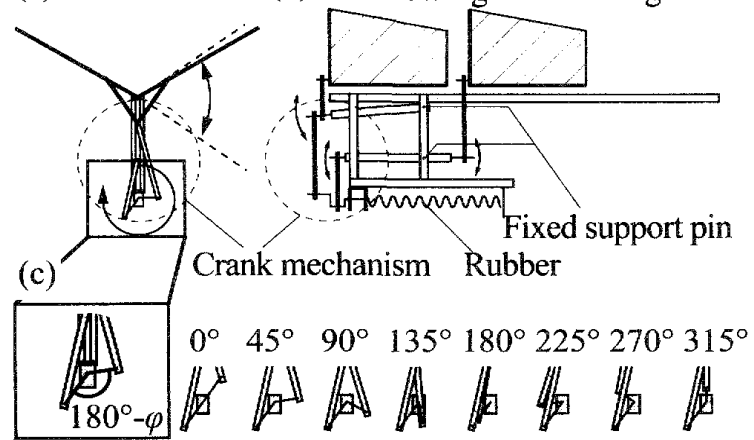

(d)

$100 \mathrm{~mm}$

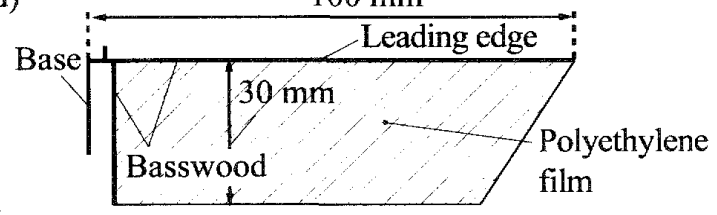

Fig. 3 (a) Front view of the design of slider crank mechanism, (b) Side view of the design, (c) Relationship between the phase relationship and the crank angle, (d) Design of the wing 
機構で上下運動に変換し羽ばたく [図 3(a)，(b)]. 従来トンボの羽ばたき周波数は $20 \mathrm{~Hz}$ から $40 \mathrm{~Hz}$ 程 度であるが(9), レイノルズ数を合わせるために, 羽ば たき機の羽ばたき周波数は $10 \mathrm{~Hz}$ に設計した。前翅 と後翅の羽ばたき運動に位相差を与えるために, 各羽 ばたき機のピアノ線で製作したクランクの腕の角度を 変えて取り付けた [図 3(c) ]. (180⼀取り付ける角 度)が前翅と後翅の位相差となる、羽ばたき位相差を $0^{\circ}$ から $315^{\circ}$ まで $45^{\circ}$ 刻みで位相差の異なる機体を試 作した。

機体の構造には断面 $0.5 \times 2.0 \mathrm{~mm}$ と断面 $1.0 \times 1.5$ $\mathrm{mm} の 2$ 種類のシナ材をそれぞれ場所に応じて使用 した. 総重量は $0.8 \mathrm{~g}$ である. 翅の前緑には $0.5 \mathrm{~mm}$ 角のシナ材を軸として用い, 翼面は厚さ $0.01 \mathrm{~mm} の$ ポリエステルフィルムを用いた [図 $3(\mathrm{~d})]$.このと き羽ばたき機の翼面荷重は $1.3 \mathrm{~N} / \mathrm{m}^{2}$ となる。

\section{3. 飛 行 実 験}

羽ばたき位相差による飛行への影響を調べるため に, 各羽ばたき位相差を持った機体の飛行を高速度力 メラで計測した。まず羽ばたき機に手動で初速を与兄 た飛行を計測した，次に初速がない状態からの飛行を 計測し, 各位相差における加速運動の違いを観察し た.

$3 \cdot 1$ 定常前進飛行 羽ばたき機は初速が遅すぎ ると塗落し, 初速が速すぎると機体は上向きに反り返 る. 適切な初速を与えると, 機体は前方洝定して飛 行する. 各位相差に扔ける定常飛行速度を計測するた めに, その中で安定した飛行が得られた場合について, 真横加ら高速度カメラ(500 frame/sまたは 1125 frame/s)で撮影し，運動を解析した。撮影した動画を
パソコンに取り込み，モニター上でフレーム毎に羽ば たき機の機首, 機尾の座標を手動で抽出した。座標抽 出に伴うノイズはカットオフ周波数 $25 \mathrm{~Hz}$ のローパ スフィルタで平滑化した。これらの座標から速度を求 めた。

各羽ばたき位相差における飛行軌跡と水平飛行速度 を図 4 に示吉．飛行軌跡は機体の位置と姿勢を $20 \mathrm{~ms}$ ごとにプロットしている.どのような位相差の機体で あっても適切な初速を与えれば, ほほ平平に飛行し た。図4 の各飛行に扔ける平均前進飛行速度を図 5 に 示す．位相差 $180^{\circ}$ のとき全ての機体の中で最も遅い 速度で飛行し, 平均速度は $0.6 \mathrm{~m} / \mathrm{s}$ であった[図 5(a)]. 羽ばたき位相差が大きい $270,315^{\circ}$ のとき， 速度は他の位相差の機体上り速く飛行し, 平均速度は $2.0 \mathrm{~m} / \mathrm{s}$ 程度で西った [図 $5(\mathrm{~b}),(\mathrm{c})]$. 位相差 $0^{\circ}$ から $225^{\circ}$ の場合の平均速度は $180^{\circ}$ の場合を除いて $1.0 \mathrm{~m} / \mathrm{s}$ から $1.5 \mathrm{~m} / \mathrm{s}$ 程度であった。羽ばたき機は発 進時の初期条件などの影響を受けるのでまったく同一 の飛行を繰り返すことはないが, 羽ばたき位相差によ る飛行速度が異なることは再現性があった。

$3 \cdot 2$ 加速前進飛行 各羽ばたき位相差における 加速前進運動を計測するために, 初速 $0 \mathrm{~m} / \mathrm{s}$ の状態か らの飛行を $3 \cdot 1$ 節と同様に高速度カメラを用いて撮影 した，座標データの作成やフィルタリングによるノイ ズの除去は $3 \cdot 1$ 節と同様に行った。機体をピンで支柱 に固定した状態で羽ばたきを開始した後, 機体を固定 するピンを抜くことで, 羽ばたき機は初速度を $0 \mathrm{~m} / \mathrm{s}$ の状態から発進する(図 6).

その結果, 位相差 $45^{\circ}$ と位相差 $180^{\circ}$ の機体のみが 飛行可能であった[図 7(a), (b)].な押, 定常前進 飛行実験と同様汇飛行軌跡注機体の位置と姿勢を 20

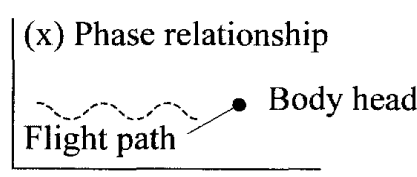

(a) $0^{\circ}$

(a) $0^{\circ}$

(c) $90^{\circ}$

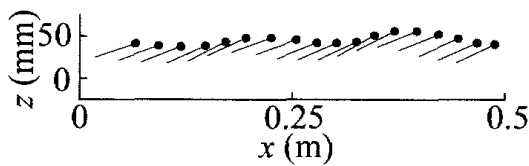

(d) $135^{\circ}$ (f) $225^{\circ}$

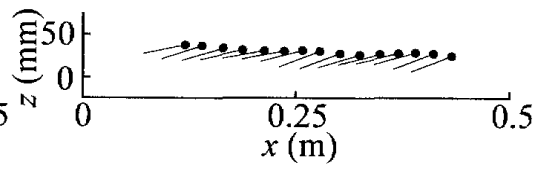

(g) $270^{\circ}$

(b) $45^{\circ}$

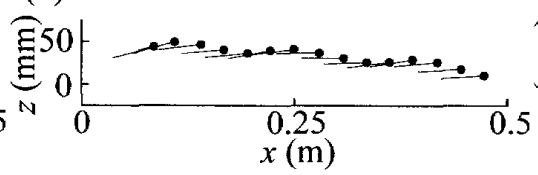

(e) $180^{\circ}$

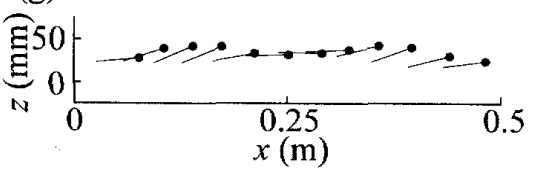

(h) $315^{\circ}$
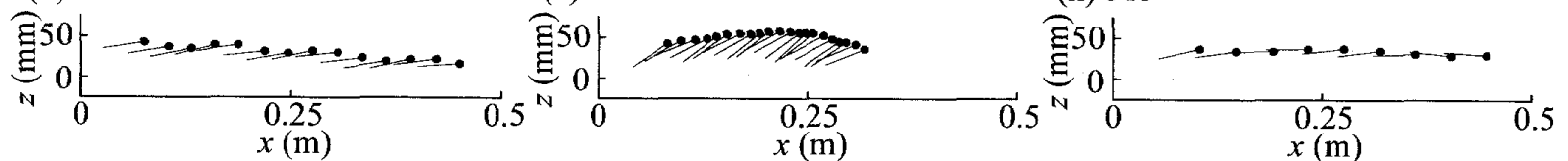

Fig. 4 Flight path of the DTOs in steady flight. (a ) $\varphi=0^{\circ}$, ( b ) $\varphi=45^{\circ}$, (c) $\varphi=90^{\circ}$, (d) $\varphi=135^{\circ}$, (e) $\varphi=180^{\circ}$, (f) $225^{\circ}$, (g) $\varphi=270^{\circ}$, (h) $\varphi=315^{\circ}$ 


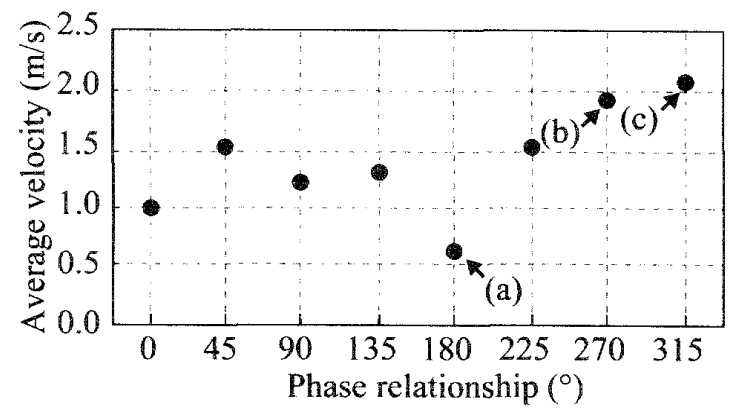

Fig. 5 Relationship between average velocity and phase relationship. (a) $\varphi=180^{\circ}$, (b ) $\varphi=270^{\circ}$, (c) $\varphi=315^{\circ}$

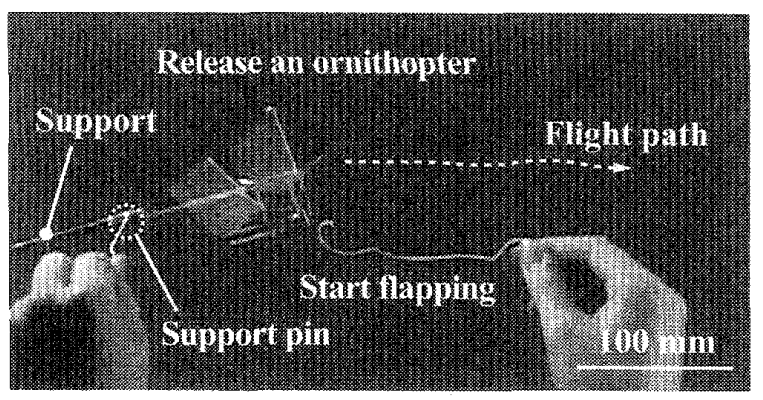

Fig. 6 Experimental setup of acceleration flight

(a)

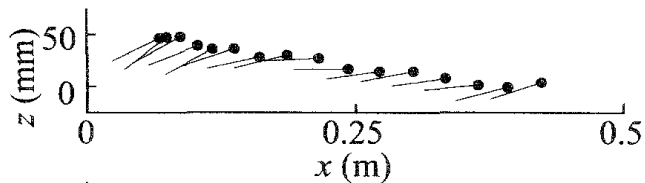

(b)

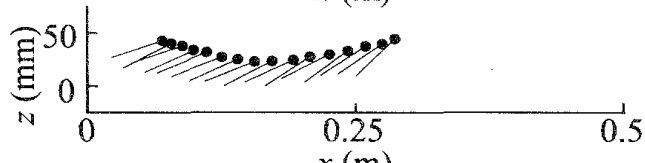

(c)

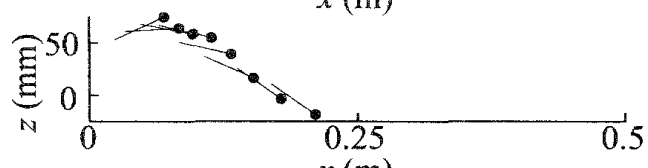

(d)

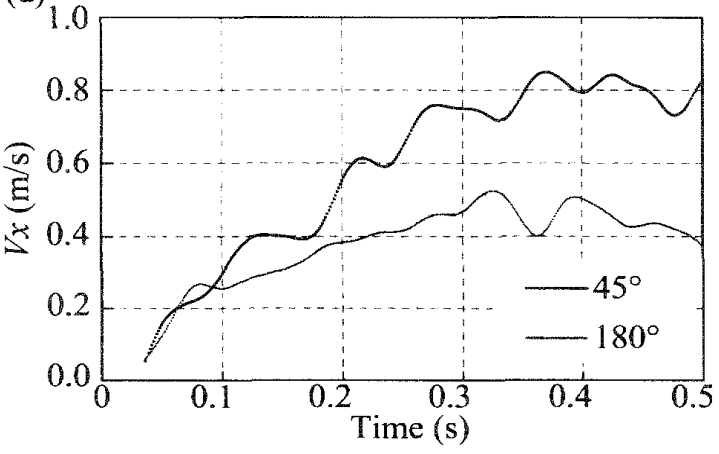

Fig. 7 Flight path of the ornithopters in acceleration flight. (a ) $\varphi=45^{\circ}$, (b ) $\varphi=180^{\circ}$, (c) $\varphi=315^{\circ}$, (d) Forward velocity

msごとにプロットしている。位相差 $45^{\circ}$ の機体は初 速 $0 \mathrm{~m} / \mathrm{s}$ から $0.5 \mathrm{~s}$ 後には $0.8 \mathrm{~m} / \mathrm{s}$ まで加速し飛行し た [図 7(d)]。一方位相差 $180^{\circ}$ の機体は初速 $0 \mathrm{~m} / \mathrm{s}$
Table 2 Summary of flight experiment

\begin{tabular}{|c|c|c|}
\hline $\begin{array}{c}\text { Phase } \\
\text { relationship }\end{array}$ & $\begin{array}{c}\text { Forward } \\
\text { velocity }\end{array}$ & Acceleration flight \\
\hline $45^{\circ}$ & $1.5 \mathrm{~m} / \mathrm{s}$ & High acceleration \\
\hline $180^{\circ}$ & $0.6 \mathrm{~m} / \mathrm{s}$ & Low acceleration \\
\hline $270^{\circ}, 315^{\circ}$ & $2.0 \mathrm{~m} / \mathrm{s}$ & Fall \\
\hline
\end{tabular}

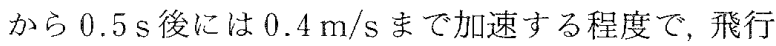
速度は位相差 $45^{\circ}$ の機体に比べ遅く，加速度が小さか った．位相差 $45^{\circ}$ と位相差 $180^{\circ}$ 以外の位相差の機体 は，適切な初速を与えると機体は安定して飛行するが， 初速 $0 \mathrm{~m} / \mathrm{s}$ の場合, 体軸のバランスを崩して薩落, ま たは揚力が足らず下降した。図7(c)のように墜落し た機体に扔いては機体の体軸角が後翅の打ち下げによ って急激に減少していた。定常飛行の実験と同様に， 羽ばたき位相差により加速前進飛行速度が異なること は再現性があった。

$3 ・ 3$ 飛行実験のまとめ定常前進飛行扮よび加 速前進飛行の実験において，位相差ごとに定常飛行速 度抢よび初速 $0 \mathrm{~m} / \mathrm{s}$ の状態からの飛行軌跡が異なっ た。その中でも位相差 $45,180,270,315^{\circ}$ の機体の飛 行は特徴的な飛行であった(表2).

位相差 $45^{\circ}$ では定常飛行速度は $1.5 \mathrm{~m} / \mathrm{s}$ 程であった が，初速 $0 \mathrm{~m} / \mathrm{s}$ の状態加らの加速飛行実験においては 他の位相差と違って䜃落も下降もせず加速し飛行し た.

位相差 $180^{\circ}$ では低速飛行を行う傾何が観察された。 定常飛行速度が遅く，0.6 m/s 程度であった。また加 速飛行実験においては，丞落または下降はせず遅い加 速度で加速し飛行した。

位相差 $270,315^{\circ}$ では速度は，他の位相差の機体よ り速い傾向があり，2.0 m/s 程であった。加速飛行実 験に㧍いては，体軸のバランスを崩して墜落した。

\section{4. 流れの可視 化}

$4 \cdot 1$ 実験装置と方法 3 章の飛行実験で特徴的 な飛行を行った羽ばたき位相差について，羽ばたき位 相差が翅まわりの流机へ与える影響党調べるために， 風洞で煙による流れの可視化を行った[図8(a)]。 羽ばたき位相差 $45,180,315^{\circ}$ について, 羽ばたき運 動時の翅まわりの流れを観察した．位相差 $270^{\circ}$ と位 相差 $315^{\circ}$ は同じ傾向を示すので, $315^{\circ} 2 つ の$ 位相 差の代表值とした。羽ばたき機の飛行速度は $0.6 \mathrm{~m} / \mathrm{s}$ から $2.0 \mathrm{~m} / \mathrm{s}$ であるが，使用した風洞の特性上，流速 $1.0 \mathrm{~m} / \mathrm{s}$ と $1.5 \mathrm{~m} / \mathrm{s}$ の 2 種類の一定な流速で実験を行 った。風洞内流速 $1.0 \mathrm{~m} / \mathrm{s} と 1.5 \mathrm{~m} / \mathrm{s}$ での実験法, そ れぞれ低速，高速な飛行速度での羽ばたき機の飛行に 

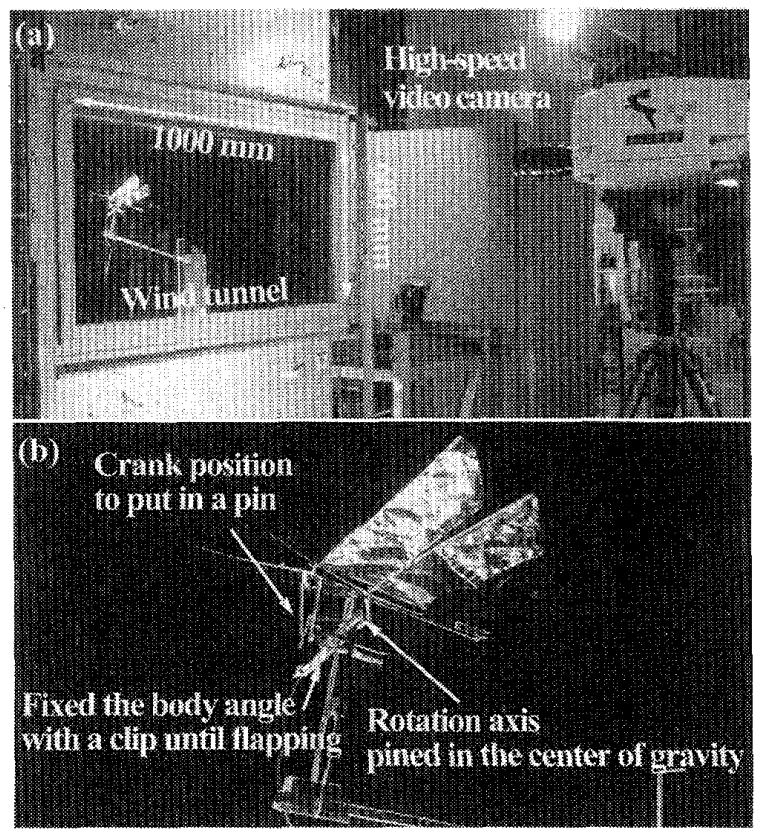

Fig. 8 Photographs of experimental setup to visualize airflow around the wings. (a) A wind tunnel and a high speed video camera, (b) Tethered ornithopter in the wind tunnel

対応する。

風洞内で羽ばたき機が羽ばたき運動を行う際, 重心 まわりに回転できるように固定した $[$ 図 $8(b)]$. 機 体の位置は固定されるが, 体軸角は自由に動く. 体軸 角が变化することで, 完全に固定した状態で観察する よりも自由飛行に近い状態で観察できる。そのため纪 機体の重心位置に穴を開け，ピンを通し，ピンを固定 することで重心まわりに回転できるようにした。

風洞は開放型吹出式風洞を使用した。測定部の大き さは縦 $600 \mathrm{~mm}$, 横 $1200 \mathrm{~mm}$, 幅 $250 \mathrm{~mm}$ である. 煙 はスモークワイヤ法で発生させた。ワイヤは直径 $0.32 \mathrm{~mm}$ のニクロム線を用い,トレーサとして流動 パラフィンを塗布した。翅が水平状態のときに左翼の 付け根から翼幅方向に $50 \mathrm{~mm}$ の位置を煙が横切るよ うにワイヤを設置した。

$4 \cdot 2$ 羽ばたき位相差の違いによる流れの変化 各羽ばたき位相差における翅まわりの流れを図 9 に示 す。翅まわりの流れの状態として，流れが剥がれずに 翼面に沿って流れているか，流れが前翅扔上び後翅の 前縁から剥離しているか, また LEV(Leading Edge Vortex)が発生しているが注目する。

位相差 $45^{\circ}$ では低速の場合, 高速の場合ともに後翅 は前翅化追従し, 前後翅まかりの空気の流れは剥がれ ずに翼面に沿っていた [図 9(a)，(b)]. 流れが剥が れずに翼面に沿っている場合, 定常翼理論では, 飛行 に適度な揚力が発生すると考兄られている。この仮定
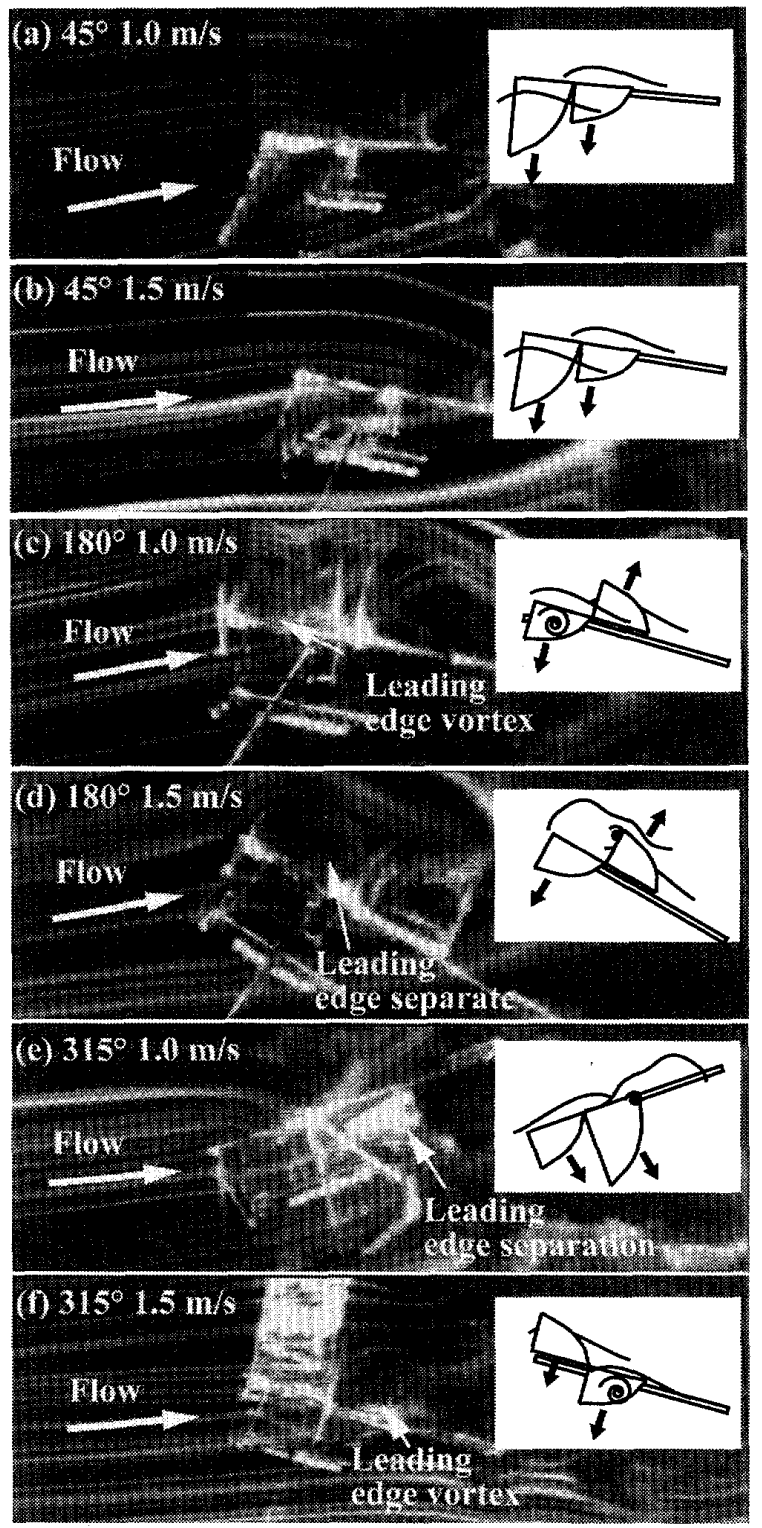

Fig. 9 Photographs of the airflow around the wings. (a) $\varphi=45^{\circ}$ with $1.0 \mathrm{~m} / \mathrm{s}$ flow, (b) $\varphi=45^{\circ}$ with $1.5 \mathrm{~m} / \mathrm{s}$ flow, (c) $\varphi=180^{\circ}$ with $1.0 \mathrm{~m} / \mathrm{s}$ flow, (d) $\varphi=180^{\circ}$ with $1.5 \mathrm{~m} / \mathrm{s}$ flow, (e) $\varphi=315^{\circ}$ with $1.0 \mathrm{~m} / \mathrm{s}$ flow, (f) $\varphi=315^{\circ}$ with $1.5 \mathrm{~m} / \mathrm{s}$ flow

に基づけば，位相差 $45^{\circ}$ は低速，高速ともに飛行に適 する位相差であると考えられる。

位相差 $180^{\circ}$ では流速 $1.0 \mathrm{~m} / \mathrm{s}$ のき前翅打ち下ろ しの際, 前翅の上纪 LEV が発生した $[$ 図 $9(\mathrm{c})]$. 打 ち下ろしの際の LEV の付着は羽ばたき飛行において 揚力が増大する効果があるといわれている(2). 流速 $1.5 \mathrm{~m} / \mathrm{s}$ のと前翅の流れが剥離した [図 $9(\mathrm{~d})]$. 流机の剥離は, 定常翼理論では, 抗力が増大し, 飛行 に不適である流れであると考えられている。したがっ て位相差 $180^{\circ}$ は飛行にとって, 低速飛行の場合は, 前 翅に LEV が発生することにより揚力が増大するが, 
Table 3 Summary of visualization experiment

\begin{tabular}{|c|c|c|}
\hline $\begin{array}{c}\text { Phase } \\
\text { relationship }\end{array}$ & Slow speed flow & High speed flow \\
\hline $45^{\circ}$ & Smooth & Smooth \\
\hline $180^{\circ}$ & LEV on forewing & Separation \\
\hline $315^{\circ}$ & Separation & LEV on hindwing \\
\hline
\end{tabular}

高速飛行の場合㹥れが剥離することにより失速する ことになると考えられる。

位相差 $315^{\circ}$ では流速 $1.0 \mathrm{~m} / \mathrm{s}$ のを後翅打ち下ろ しの際，後翅の流れが剥離した[図 $9(\mathrm{e})]$ 。流速 1.5 $\mathrm{m} / \mathrm{s}$ のを流れは剥離せず後翅の上に LEVが発生し た [図 $9(\mathrm{f})]$ 。このことにより，位相差 $315^{\circ}$ は飛行 にとって，低速飛行の場合は失速するが，高速飛行の 場合は揚力が増大することになると考えられる。

この美験から，表 3 のよに各羽ばたさ位相差によ って, 翅まわりの空気の流れの様子が異なり，流速の 変化に応じて, 飛行に適するもの, 適さないものが存 在することが分かった。

\section{5. 羽ばたき位相差と飛行速度}

飛行実験之可視化実験をまとめて考察する，位相差 $45^{\circ}$ は初速 $0 \mathrm{~m} / \mathrm{s}$ 加加速し, 低速, 高速ともに流れ が剥がれずに翼面に沿っていた。したがって低速域か ら高速域へ遷移寸る加速飛行に適していると考えられ 3.

位相差 $180^{\circ}$ では，低速飛行の場合は前翅に LEVが 発生することにより揚力が増大するが, 高速飛行の場 合流れが剥離することにより失速すると考えられ る。したがって低速飛行に適していると考えられる。 位相差 $270,315^{\circ}$ では，初速 $0 \mathrm{~m} / \mathrm{s}$ からでは飛行し なかった。また低速飛行の場合は, 後翅の流れが剥離 することにより失速するが, 高速飛行の場合は, 後翅 の上に LEV が発生することにより揚力が増大すると 考えられる。したがって位相差 $270,315^{\circ}$ は高速飛行 に適していると考えられる。

このように飛行速度によって適する羽ばたき位相差 が存在すると考えられる。

\section{6. 結言}

本研笢では，羽ばたき機を用いて，トンボの羽ばた き飛行における前翅と後翅の羽ばたき位相差の役割を 明らかにした。まずトンボの羽ばたき飛行の特幑をモ デル化し，トンボ型羽ばたき機の設計指針とした。そ の設計指針を満たす翼長 $100 \mathrm{~mm}$, 質量 $0.8 \mathrm{~g}$, 羽ばた き周波数 $10 \mathrm{~Hz}$ のトンボ型羽ばたき機を試作した。 羽ばたき位相差が $0^{\circ}$ から $315^{\circ} ま て ゙ ~ 45^{\circ}$ 刻みで位相差
Table 4 Relationship between the phase relationship of dragonflies ${ }^{(9),(10)}$ and that of the DTO

\begin{tabular}{|c|c|c|}
\hline Flight mode & Dragonfly & DTO \\
\hline High speed & $260^{\circ}-306^{\circ}$ & $270^{\circ}, 315^{\circ}$ \\
\hline Low speed & $180^{\circ}$ & $180^{\circ}$ \\
\hline Accelerating & $0^{\circ}$ & $45^{\circ}$ \\
\hline
\end{tabular}

の異なる機体の飛行を計測したところ, 定常飛行速度 及び加速運動の様子は位相差によって異なった．また 機体まわりの流れの可視化を行ったところ, 羽ばたき 位相差によって, 流れの様子が異なった。流速の変化 に応じて, 飛行に適するもの, 適さないものが存在し た。これらの結果から試作した羽ばたき機では位相差 $45^{\circ}$ は加速飛行に, 位相差 $180^{\circ}$ 注低速飛行に, 位相差 $270,315^{\circ}$ は高速飛行に適していることが示された。 これらの関係は，実際のトンボが使い分ける羽ばたき 位相差と飛行の関係に医卧一致する(表 4)。以上の結 果からトンボ型の羽ばたき飛行に扔いて, 飛行速度に よって適する羽ばたき位相差が存在することが示され た。このことはトンボが羽ばたき位相差を利用して， 機動的な飛行を行っていることを示唆する。

\section{謝辞}

風洞実験に関して助言, 協力していただいた東京大 学大学院工学系研究科航空宇宙工学専攻 河内啓二教 授に感謝する。また本研究は, 文部科学省科学研究費 補助金基盤研究(S)（課題番号 18100002）の交付を受け て行われた。

\section{文献}

(1) Ellington, C.P., The Novel Aerodynamics of Insect Flight: Applications to Micro-Air Vehicles, Journal of Experimental Biology, Vol. 202 (1999), pp. 34393448 .

(2) Combes, S. A. and Daniel, T. L., Flexural Stiffness in Insect Wings II, Spatial Distribution and Dynamic Wing Bending, Journal of Experimental Biology, Vol. 206 (2003), pp. 2989-2997.

(3) Lehmannl, F.-O., Sane, S. P. and Dickinson, M., The Aerodynamic Effects of Wing-Wing Interaction in Flapping Insect Wings, Journal of Experimental Biology, Vol. 208 (2005), pp. 3075-3092.

(4) Birch, J. M. and Dickinson, M. H., Spanwise Flow and the Attachment of the Leading-Edge Vortex on Insect Wings, Nature, Vol. 412 (2001), pp. 2257-2272.

(5) Ellington, C. P., Van den Berg, C., Willmott, A. P. and Thomas, A. L. R., Leading-Edge Vortices in Insect Flight, Nature, Vol. 384 (1996), pp. 626-630.

(6) Dickinson, M. H., Lehmann, F. O. and Sane, S. P., Wing Rotation and the Aerodynamic Basis of Insect Flight, Science, Vol. 284 (1999), pp. 1954-1960.

(7) Sane, S. P. and Dickinson, M. H., The Aerodynamic Effects of Wing Rotation and a Revised Quasi- Steady 
Model of Flapping Flight, Journal of Experimental Biology, Vol. 205 (2002), pp. 1087-1096.

(8) Alexander, D. E., Unusual Phase Relationships Between the Forewings and Hindwings in Flying Dragonfly, Joumal of Experimental Biology, Vol. 109 (1984), pp. 379-383.

(9) Wakeling, J. M. and Ellington, C. P., Dragonfly Flight II, Journal of Experimental Biology, Vol. 200 (1997), pp. $557-582$.

(10) Azuma, A. and Watanabe, T., Flight Performance of a Dragonfly, Journal of Experimental Biology, Vol. 137 (1988), pp. 221-252.

(11) Wang, H., Zeng, L., Liu, H. and Yin, C., Measuring Wing Kinematics, Flight Trajectory and Body Attitude During Forward Flight and Turning Maneuvers in Dragonflies, Journal of Experimental Biology, Vol. 206 (2003), pp. 745-757.

(12) May, M. L., Dragonfly Fight: Power Requirements at High Speed and Acceleration, Journal of Experimental Biology, Vol. 158 (1991), pp. 325-342.

(13) Tomas, A. L. R., Taylor, G. K., Srygley, R. B., Nudds,
R. L. and Bomphrey, R. J., Dragonfly Flight: FreeFlight and Tethered Flow Visualizations Reveal a Diverse Array of Unsteady Lift-Generating Mechanism, Controlled Primarily Via Angle of Attack, Jour nal of Experimental Biology, Vol. 207 (2004), pp. 42994323.

(14) Wang, J. K. and Sun, M., A Computational Study of the Aerodynamics and Forewing-Hindwing Interaction of a Model Dragonfly in Forward Flight, Journal of Experimental Biology, Vol. 208 (2005), pp. 3785-3804.

(15) Sun, M. and Lan, S. L., A Computational Study of the Aerodynamic Forces and Power Requirements of Dragonfly Hovering, Joumal of Experimental Biology, Vol. 207 (2004), pp. 1887-1901.

(16) Maybury, W. J. and Lehmann, F. O., The Fluid Dynamics of Flight Control by Kinematic Phase Lag Variation Between Two Robotic Insect Wings, Journal of Experimental Biology, Vol. 207 (2004), pp. 47074726.

(17) Azuma, A., Encyclopaedia of Biomechanics (in Japanese), (1997), p. 129, Asakura shoten. 